This is the version of the article accepted for publication in New Political Economy published by Taylor \& Francis: http://dx.doi.org/10.1080/13563467.2017.1259299

Accepted version downloaded from SOAS Research Online: http://eprints.soas.ac.uk/23267/

\title{
The Material and Culture of Financialisation
}

\section{Ben Fine}

\section{Introduction}

Our introduction to the symposium in part, through reference to interest bearing capital, commodification, and so on, offered what Erturk et al. (eds) (2008) would dub a political economy of financialisation, preparing the way in this paper to embed this within a material culture of financialisation, mcf. In our (post)postmodern world, what this means, let alone how to do it, is extremely controversial and open. The concern will be with what (often unacknowledged and unrecognised as such) financialisation means to its subjects (or objects) and how those meanings are liable to be generated. Necessarily, this involves differentiating between subjects - the futures trader as opposed to the unemployed, let alone the incidence of other individual and social characteristics - and how these subjects both interact with, and reflect upon, the various dimensions of financialisation as they experience them.

To traverse this potentially contested and, to a large extent, unchartered terrain the system of provision, or SoP, approach will be developed to study the mcf. ${ }^{1}$ This approach is adopted with some hesitation because, although financial services can have been perceived as a consumption good (as well as a productive input), they are clearly something much more than, and different from, this. On the other hand, especially in the light of financialisation and much other literature that has both addressed and preceded it, the notion of the presence of a financial system is pervasive from many different perspectives and, of necessity, this involves the presence of material processes, structures, relations and agents (or agencies) and the systems of meanings with which they are formed and interact with one another. This is what allows the mcf to be framed within the SoP approach, drawing in particular upon the 10Cs associated with it, that the mcf is Constructed, Construed, Conforming, Commodified, Contextual, Contradictory, Closed, Contested, Collective, and Chaotic, (Bayliss et al. this 
This is the version of the article accepted for publication in New Political Economy published by Taylor \& Francis: http://dx.doi.org/10.1080/13563467.2017.1259299

Accepted version downloaded from SOAS Research Online: http://eprints.soas.ac.uk/23267/

issue). Given the origins of the SoP approach, some parallels will usefully be drawn between mcf and the material culture of consumption, particularly food, although not addressing the financialisation of food itself. ${ }^{2}$ Significantly, despite the weight of financialisation of food, its impact upon food's material culture, what we consume and what it means to us, seems distant if not negligible and unknown - at least until we start to look at, for example, systemic levels of malnutrition and obesity. In this respect, as will become apparent, there are considerable resonances with the mcf. By use of the 10Cs, the diverse pathways, by which the Foucauldian governance of the financialisation of everyday life prevails, can be fully confronted.

\section{From SoP to finance}

The SoP approach to the material culture of consumption can be presented by taking Haug's (1986) notion of "aesthetic illusion" as critical point of departure. Haug suggests that capitalist production degrades commodities as a means of cheapening them, and they can only be successfully sold by compensating for this degradation (and adulteration) ${ }^{3}$ by endowing them with meanings (and hence enhanced use value and appeal) through advertising that, for him in particular, deploys the persuasive powers of sexuality.

This approach, however, suffers a number of deficiencies: production may become of higher not lower quality (through changes in processes, products and ingredients); advertising and sexuality are not the only, even major, determinants in bridging the putative aesthetic illusion; and, most important, how are the two sides of the aesthetic illusion (commodity as is relative to commodity as perceived) generated, reproduced and/or transformed and bridged as far as the consumer is concerned. In this respect, the aesthetic illusion can itself be seen to be illusory as it dissolves into investigating the meanings of consumption directly through its constituent determinants rather than indirectly through how it was previously and subsequently understood (and experienced) in light of change in provisioning. In other words, there is no possibility of bridging the gap spanned by the aesthetic illusion without knowing 
This is the version of the article accepted for publication in New Political Economy published by Taylor \& Francis: http://dx.doi.org/10.1080/13563467.2017.1259299

Accepted version downloaded from SOAS Research Online: http://eprints.soas.ac.uk/23267/

where the two sides are -which themselves shift - and how they are (re)formed. So the commodity as is and as understood might just as well be addressed directly without reference to the aesthetic illusion.

The question is how. And, here at least, the aesthetic illusion offers some guidance in having pointed in a limited way to the ensemble of factors (if illegitimately confined to product degradation and sexualised advertising) that comprise the material practices and experiences that underpin the meaning of the consumed to the consumer. Furthermore, and this is characteristic of commodity consumption, ${ }^{4}$ those experiences and meanings are of two types - those that precede purchase (from which the consumer is essentially absented with minor, possibly exaggerated, exceptions in case of "custom built", relevant for personal financial plans, or the more general notion of trickle effects of consumer sovereignty) and those that follow it (although there are cycles of consumption and production). Significantly, there is some case to be made for an aesthetic illusion attached to finance as, especially with misselling, financial products are presented as other than they are, together with varieties of powers of persuasion (if not, generally, sexuality as opposed to less risky markers of security and reward, around the home, family and life choices such as fertility and retirement, for example).

In short, it is imperative to construct an understanding of financialisation and its material culture, or cultures, in tandem and balance with one another. Even for performativity, which emphasises the role of economists in making (financial) markets rather than vice-versa, and its most developed illustration, the Black-Scholes model as examined by McKenzie (2008), it is questionable whether financialisation would have failed to progress without the, arguably more important, pressures to liberalise financial markets (Fine 2016). For financialisation has witnessed the geographical, or internationalised, expansion of financial markets both nationally and internationally, with such activity breaching a rather different boundary by 
This is the version of the article accepted for publication in New Political Economy published by Taylor \& Francis: http://dx.doi.org/10.1080/13563467.2017.1259299

Accepted version downloaded from SOAS Research Online: http://eprints.soas.ac.uk/23267/

being reinterpreted as constituting a contribution to GDP as opposed to mere transfers of income. ${ }^{5}$ This is much more reflected than precipitated in the reconstruction of finance in the economics literature. And it is telling just how narrow has been the scope of application of the performativity thesis given the range and impact of financial markets involved.

\section{MCF is Constructed and Construed}

More specifically, in contrast to performativity's emphasis on how economics makes the economy (and hence financialisation), the SoP approach to the material culture (of consumption) proceeds by reference to 10 characteristics, known as the $10 \mathrm{Cs}$. And these will be applied here to the financial system (and financialisation). First, the financial system is Constructed (and reconstructed) through its material practices. ${ }^{6}$ By this is understood not simply nor primarily the self-reflection upon the meanings attached to financialisation by financial subjects themselves. Rather how those meanings emerge depends upon the workings of the financial system itself as these evolve, impact and induce response in thought and deed. Such an approach is deemed essential because of the presumption (significantly, denied by performativity) that capitalism (and its associated financial system and financialisation) incorporate relations, structures and processes, within or against which agents must themselves react. This is not to suggest absence of independent agency only to situate it systemically, with different approaches to this displaying differences of emphasis, methods and theories around corresponding modes of interaction. ${ }^{7}$

Second, though, financial systems are Construed. Just as the consumer can be cynical about the sexuality deployed to promote (degraded) goods, so those engaging with the financial system do not necessarily accept the wisdoms or otherwise that it conveys deliberately or otherwise. Whatever the sources of experience and knowledge, these are reflected upon to a greater or lesser extent, and reacted to, or against, rather than simply received passively (which would also beg the question of who created the meanings that are being conveyed 
This is the version of the article accepted for publication in New Political Economy published by Taylor \& Francis: http://dx.doi.org/10.1080/13563467.2017.1259299

Accepted version downloaded from SOAS Research Online: http://eprints.soas.ac.uk/23267/

alongside financial dealings). Cook et al. (2009), for example, ask homeowners to construe mortgaging in terms of animal-types. And, for Payne (2012), the right to buy a home is seen as an attempt to induce the culture of neoliberal consumer, see also (Robertson this issue). This conditioned construal of financialisation can be taken further and, once again, comparisons with consumer (or, more exactly food) culture is telling not least by reference to Fischler's (1988) 'omnivore's paradox' as critical point of departure. He suggests that, because we can eat anything, we run the risk of poisoning contingent upon our knowledge of food. But, he argues, our knowledge, and its attachment to potential harm or distaste (think horse meat), has been increasingly undermined by detachment from food's production, a consequence of (global) commodification bringing physical as well as knowledge distance from the sources of our diets in processes of production and distribution. As argued by Fine (1993 and 1998), however, by reference to what he terms the "diet paradox", our knowledge of the food is considerably greater in many respects than of our directly producing and consuming peasant ancestors if such they were. This is because direct knowledge and experience of production (and processing, wholesaling and retailing) are not the only sources of knowledge in general and of these elements in particular. Indeed, our current common knowledge of nutritional properties of foods did not exist as such in olden times, however nostalgically viewed.

But this does not mean that we organise our eating habits around such knowledge in the sense that we have a healthy diet that we target. Such is the rationale for posing the 'diet' in place of the 'omnivore's paradox since, whilst everyone does have a diet ex post, it is not necessarily determined as such by ex ante intentions. Nor does it make sense to understand the determinants of diet by more or less deviation from what is constructed and construed to be ideal in healthy eating advice even if this does have some, not necessarily positive, influence. Further, how our knowledge and meanings of food are generated remains to be 
This is the version of the article accepted for publication in New Political Economy published by Taylor \& Francis: http://dx.doi.org/10.1080/13563467.2017.1259299

Accepted version downloaded from SOAS Research Online: http://eprints.soas.ac.uk/23267/

explored (as descriptors like fair trade, organic, natural, and so on, are themselves constructed and construed as much by factors other than the physical properties of the foods themselves and how they are provided).

In case of financialisation, however, we are endowed with parallel paradoxes as for food, not least concerning our knowledges of finance. Despite the limited presence of immediate physical properties as such in monetary relations (as they are performed by a paper or even electronic service in many instances), there is the presence of both omnivore's (displaced ignorance) and diet (multiple sources of knowledge) paradoxes with finance. To a large extent, other than in a token way with the minor resurgence of behavioural economics in the wake of the crisis, such absence of knowledge has been overlooked by mainstream economics (and much heterodoxy) or reduced to imperfect information or uncertainty. This follows from the presumption of the rational, optimising individual, subject only to budget and informational constraints, or otherwise deviant from rationality as exception to the norm. In this imaginary world of the efficient market hypothesis for financial markets, the omnivore's paradox simply disappears with optimal use of information subject to costs of gaining it

However, outside of the confines of orthodox economics, and in more or less explicit response to financialisation, the literature has pointed to the limits in knowledge that are attached to finance. The omnivore's paradox applies much more to finance than to food and much the same if not more is true of the diet paradox. Finlayson (2009: 402) suggests that, 'there has been a reduction of the distance between high finance and everyday life, a lowering of the barriers between global banking and household finance'. But, to the contrary, our distance in knowledge of finance, despite what may or may not be its physical proximity on a daily basis, is considerable, far more distant than our knowledge of agriculture, etc, if such comparisons are meaningful. As Langley (2008: 3) puts it, 'the majority of mortgagors, credit 
This is the version of the article accepted for publication in New Political Economy published by Taylor \& Francis: http://dx.doi.org/10.1080/13563467.2017.1259299

Accepted version downloaded from SOAS Research Online: http://eprints.soas.ac.uk/23267/

card holders, and other borrowers seem unaware that claims on their future repayments, and the risks on their non-payment, are presently packaged and traded in the capital markets.' Further, as suggested above, the diet paradox's denial of a healthy diet around which consumers organise their eating habits applies equally to finance, not least by analogy with (optimisation around) the (household) budget constraint. The budget constraint is in a sense unavoidable. But this does not imply that households organise their finances around their budget constraint, consciously or otherwise, just as consumers do not target a healthy diet (and, if they do, the evidence is that they have failed miserably given rising levels of obesity to epidemic proportions). This is not to say that a healthy budget (like a healthy diet) plays no role in financial affairs (what we eat), only that it is not the only nor necessarily the primary consideration or driving force behind behaviour and meanings. Nonetheless, of course, that the budget constraints (or dietary norms) do exist and that, as a matter of tautology, behaviour revolves around some ideal optimal financial arrangements to a greater or lesser extent, can lead to the delusion that targeting such optimality is how behaviour is determined. Why this might or might not be accomplished can then be taken to be what has to be explained (and as abnormal and irrational, even deviant and pathological, if excessive). Such is the analytical take on campaigns to improve behaviour, financial or dietary, by improving knowledge as with campaigns for the promotion of financial literacy and healthy eating, respectively. ${ }^{8}$ Moreover, such false conceptualisations of how households manage their financial affairs are compounded when they are projected to those of the nation as if household, rationalising austerity through balancing the books or 'handbag economics' in the terminology of Mellor's (2016: 136/7) critique, if falsely presuming the transparency, as opposed to the opacity, of how government can create public money free of debt, albeit to use it support private debt 'Quantitative easing made transparent the ability of public monetary authorities to create public currency free of debt ... it has replaced possibly toxic loans with good public money'. 
This is the version of the article accepted for publication in New Political Economy published by Taylor \& Francis: http://dx.doi.org/10.1080/13563467.2017.1259299

Accepted version downloaded from SOAS Research Online: http://eprints.soas.ac.uk/23267/

What, however, underpins the construal of finance is not that finance is unknown but that it is unknowable. This has been most forcibly put by Engelen et al. (2012: 366). For them: ${ }^{9}$

Our first claim is that finance is now technically ungovernable, so that any attempt to restore finance to some kind of equilibrium or balance is futile because instability is written into its DNA. We make this case by arguing that financial innovation takes the form of bricolage which has had four key consequences - the growth of volume, complexity, opacity and interconnectedness. With bricolage, restorative regulation ceases to be an external constraint and becomes an input for future financial improvisation by creative bricoleurs.

Further, in the context of the limitations on the knowledge to govern finance, Haldane has proven a significant, and particularly well-placed, commentator. ${ }^{10}$ He reports that Basel I at 30 pages in 1998, went to 347 pages in Basel II in 2004, and stood at 616 pages with Basel III in 2010. For the USA, the Glass-Steagall Act in 1993 took just 37 pages compared to the 848 pages of the Dodd-Frank Act of 2010 (with 400 bits of detailed rules for regulatory agencies), with a further 8,843 pages for the rulebook in covering just one third of the rules involved. Even more striking is the (employment) burden of financial regulation with one UK regulator for 11,000 financial sector employees in 1980 compared to one for every 300 today, with less than 100 increasing to over 3,000 regulatory employees involved. By the same token, in the USA, with 18,500 regulatory employees for finance, this suffices to provide three regulators for each US bank. On the other hand, demands on UK banks to meet reporting requirements have gone from 150 entries in regulatory returns to 7,500 items of data, with new European rules possibly requiring a total of over 30,000 entries over 60 different forms. Just to meet Basel III compliance over 350 European banks is estimated to support 70,000 new jobs. Three points emerge from these observations. One is that the knowledge displayed by Haldane is almost certainly a cause for shock, even disbelief, against the presumption that 
This is the version of the article accepted for publication in New Political Economy published by Taylor \& Francis: http://dx.doi.org/10.1080/13563467.2017.1259299

Accepted version downloaded from SOAS Research Online: http://eprints.soas.ac.uk/23267/

finance has been too loosely regulated and is in need of more and tighter regulation. Second,

Haldane is suggesting that finance is, indeed, more or less unknowable, and regulation should be designed accordingly, unless the wood be missed for the trees. ${ }^{11}$ Third is the sheer weight of resources being dedicated to regulation that might, alongside those used to buttress the ailing financial system as well as those lost due to its crisis, equally come as a profound shock to those supporting, let alone opposing, what is supposedly a laissez-faire source of market efficiency.

It is worth speculating what would be the reaction of households to such knowledge, if it were made available to them on a sustained basis, bearing in mind just how quickly if not completely the antipathy to finance rose and dissipated with the crisis (with its own fortunes, and rewards, following a parallel trajectory only more sharply so). It is also important to tease out why such knowledge remains distant. Here, the treatment of the crisis in the media is crucial (Happer, this issue).

The media, though, will have been informed by two other major sources of, or limitations upon, knowledge - what is received and how it is interpreted. One is scholarship within which the place of economics, including its neoliberal versions, remains prominent despite an early if uneven rush to blame the discipline for not anticipating the crisis, for not acknowledging it as a possibility, and for failing to remedy it quickly and fully. Here, neoliberal scholarship has all the bases covered: potentially blaming individuals for not making best use of knowledge should the (financial) system fail, thereby leaving unquestioned the perfect working of (financial) markets in coordinating that behaviour but for unavoidable random shocks; or highlighting the impossibility of avoiding failures of the system given imperfections in the nature of gaining and using knowledge itself; and the state can be deployed as a last resort as an impediment to the perfectly working markets from both Chicagoan and neo-Austrian perspectives. ${ }^{12}$ Whilst neoliberal scholarship, together with its 
This is the version of the article accepted for publication in New Political Economy published by Taylor \& Francis: http://dx.doi.org/10.1080/13563467.2017.1259299

Accepted version downloaded from SOAS Research Online: http://eprints.soas.ac.uk/23267/

market imperfection versions, is contested, it reigns supreme within academia and through much of the media, leading to a politics of competing TINA ideologies around how to achieve deficit reduction and the like, (Brassett et al. 2009).

\section{From Commodified to Chaotic}

Such relations between government/politics and knowledge limitations have profound implications for the democratic governance of finance. But, so obvious that it might be overlooked as, indeed, does often occur for commodity consumption, is that the material culture of finance is Commodified. Of course, money and financial assets are themselves commodities, unavoidably so unlike items of consumption in general, and they have their own particular properties, or use values, as such. Here, though, the concern is with those properties from the perspective of the household as part and parcel of the (capitalist) commodity system.

How this is itself approached is contingent upon whether a universal theory of money is adopted (as favoured here) or not (with, instead, a theory of specific and differentiated monies). Precisely because money (and financial assets) are universal (although not necessarily infinitely liquid) - they have the capacity to derive from, or to be applied to, more or less any economic and social activity - although some are more or less 'sacred' from the taint of money/commerce. Indeed, financialisation draws upon the fluidity of money by incorporating ever more economic and social activity into its circuits - as (interest bearing) capital. An immediate implication is that the material culture of money (and finance) is not and cannot be useful beyond appreciation of, and response to, experience of, and reflection upon, its universal properties. Rather, the variegated meanings of money derive from its location in more or less fluid if structured circular flows - from kindly or grasping banker through acquisition of fashion items, to payment of rent to slum landlord. This implies the mcf derives from the cacophony of economic and social relations within which it is 
This is the version of the article accepted for publication in New Political Economy published by Taylor \& Francis: http://dx.doi.org/10.1080/13563467.2017.1259299

Accepted version downloaded from SOAS Research Online: http://eprints.soas.ac.uk/23267/

embroiled as universal equivalent with, 'deep penetration of financial ideas, tropes, logics and processes into the fabric of everyday life' (Haiven 2014: 18).

This involves further implications. First, it turns upside down the multiple monies approach associated with Zelizer (1994, 1996, 1998 and 2000) and challenged by Fine and Lapavitsas (2000), Fine (2002) and Lapavitsas (2003). For the universality of finance endows its use with multiple meanings, not multiple meanings requiring multiple monies. Second, in particular, as there are many activities that lie outside the domain of money/commodification in principle (social as opposed to economic reproduction but not through the market), and the boundaries between these shift in practice as well as whether monetisation/commodification is viewed as appropriate, the use of money to purchase, or even to evaluate, is as varied in meaning as the uses themselves. In other words, it is economic and social activity that drives the use of money, not vice versa. Third, then, this all reinforces the earlier argument concerning the budget constraint as form of financial management. Individual expenditures, and earnings, are liable to incorporate a material culture and logic of their own which is rarely subject to a narrowly defined rational economic logic as opposed to one cog in a wheel of determinants. Last, there are the different aspects of monetary across three elements/processes that have facilitated financialisation: commodification, commodity form and commodity calculation, ccfcc, as specified in Bayliss et al. (this issue). As forms of finance, whether for credit in general or for profitmaking in particular, these tend to be conflated with one another, not least as the household, the (financial or non-financial) corporation, and the state are seen as similar accounting enterprises, whether it be in relation to borrowing, spending or indebtedness or the ethos surrounding these.

To some degree, these observations resonate with the received Polanyian view of the world in which a commercial (or financialised) logic is contested, in the context of labour, land and, especially, finance. ${ }^{13}$ But they also suggest an enrichment, generalisation and even break with 
This is the version of the article accepted for publication in New Political Economy published by Taylor \& Francis: http://dx.doi.org/10.1080/13563467.2017.1259299

Accepted version downloaded from SOAS Research Online: http://eprints.soas.ac.uk/23267/

the Polanyian double movement, not least with the following insights to be highlighted, at least in principle, with the need:

1. to disaggregate and widen the sphere of application of the double movement to commodities other than just land, labour and finance, with health, education and welfare, and so on, as also potentially subject to reaction against the logic of the (capitalist) market.

2. to refine the double (or, given the complex nature of commodities as use values as opposed to exchange values, should it be multi-dimensional) movements by tracing them along the material practices attached to, and determinants of, those movements beyond their representation of use values (and access to work, home and money) cultures are distinguished by much more than market provision or not as is provision itself.

3. to see the 'movements' distinctively in the context of ccfcc, not just in relation to homogenised forms of in and out of the market - user charges within a free service are different from privatisation of health although both favour the 'market'.

4. to locate these movements in relation to the (evolving) material culture of household attachment to financialisation to account for contemporary outcomes.

Such considerations necessarily and appropriately locate the material culture of financialisation in relation to commodification or, more accurately, to ccfcc. It follows that the material culture of financialisation is Conforming to such commodification even if allowing for resistance in word and deed. This raises with Marx's definition of commodity fetishism: that commodities appear, as they really are, as relations between things (as opposed to the products of human labour in definite social relations). By the same token, and more specifically, financialisation carries with it the practices and logics of strengthening the presence and expanding the scope of ccfcc. This dovetails with a corresponding (neoliberal) 
This is the version of the article accepted for publication in New Political Economy published by Taylor \& Francis: http://dx.doi.org/10.1080/13563467.2017.1259299

Accepted version downloaded from SOAS Research Online: http://eprints.soas.ac.uk/23267/

culture of individual, or individualised, responsibility, at the expense of the collective across ever-expanding terrains of economic and social life.

The result is to give rise to a strategy in which, 'Housing policy has become a branch of social policy, justified not in terms of absolute right or simple inequality but as a contribution to the equalisation of life chances ... and, beyond this, as an asset that will enable individuals to take responsibility for their own financial future', (Finlayson 2009: 407). This is seen as 'autonomisation and responsibilisation', and is equally 'evident in education, healthcare, pensions and training'. As Beggs et al. (2014: 978) put it, rounding up commodification/conformity with financial literacy:

the critical issue is not just whether individuals do or do not have capacity for financial literacy, or even whether more interventionist (paternalistic) approaches are needed. Rather it is that the agenda of financial literacy is itself a discourse of subordination to the individualism and discipline implicit in financial calculation. Moreover, this individualism is not a financial expression of democracy and of the good society, but about the facilitation of the class of capital and its new accumulation project.

Thus, commodification as an aspect of material culture does not originate with financialisation but its scope and influence is extended through ccfcc.

Nevertheless, Polanyian or otherwise, the logic of increasingly conforming to commodification is no rollercoaster with unstoppable momentum and, as already apparent, has to be put into place, or reproduced, by a transformation in material culture that has its own historical logics and traditions. Thus, the material culture of financialisation is Contextual across time, place, financial form and even individual household itself as far as detail is concerned. Such is obvious as soon as we attend to health, education, housing and pensions, in and of themselves and in terms of how they are financed whether by free public 
This is the version of the article accepted for publication in New Political Economy published by Taylor \& Francis: http://dx.doi.org/10.1080/13563467.2017.1259299

Accepted version downloaded from SOAS Research Online: http://eprints.soas.ac.uk/23267/

provision, user charges, insurance, credit card or bank loan. Material culture can, in these respects, be complex, stubborn to change or rapidly turned over (especially in relation to norms of avoiding indebtedness when confronted by equally powerful norms of household provision in face of reduced real and social wages, (Karacimen 2014)).

Yet such stabilities and volatilities, at individual and collective levels, are indicative of the Contradictory nature of the material culture of financialisation. By this is meant not inconsistency, but see Chaotic below, as opposed to the dependence of material culture on underlying social forces and tendencies. As Dodd (2016: 183) puts it:

Whilst neoliberal financialization may, ultimately, be characterized by the pathological and limitless collapsing of all social values into and under the ruthless quantitative measure of economic value, it is also, contradictorily, dependent on the forms of innovation, social reproduction and subjectivity generated in the intervals. Here, once again, an analogy with diet is compelling. As argued in case of eating disorders, the compulsions to eat and to diet are pervasive in contemporary capitalism, and each consumer has to negotiate these in thought and deed, with outcomes along a spectrum from anorexia and bulimia to obesity, (Fine 1995 and 1998). Remarkably, the food industries have managed to square the circle by simultaneously promoting what would otherwise appear to be mutually exclusive spheres (but bear in mind that dieting has primarily become about eating more and different over shifting cycles of behaviour).

The analogy with financialisation is striking once it is forged in terms of the imperatives both to save and to spend (on credit). Both of these activities are heavily promoted as financial services, and they mutually reinforce one another. As Cook et al. (2009: 136) put it:

With a flexible mortgage at the interface, housing wealth may be saved and spent: linking debts secured against the home to a wider range of long and short-term household transactions. 
This is the version of the article accepted for publication in New Political Economy published by Taylor \& Francis: http://dx.doi.org/10.1080/13563467.2017.1259299

Accepted version downloaded from SOAS Research Online: http://eprints.soas.ac.uk/23267/

Moreover, this adds to the understanding of financialisation in terms of the diet paradox, addressing why households both save and spend simultaneously. And, at a systemic level, the representation of finance as obese is not only apt but also commonplace as a metaphor, including fat cat salaries and bloated consumer credit, both individually and systemically. Yet, in the world of saving and spending (and financialisation), all are equal but some are more equal than others. In this respect, the material culture of financialisation is Closed, if not absolutely so, in that, as with finance itself, some participate in its formation more fully and with more influence than others, as well as at different nodes in the circulation of value (from City trader to indebted household) - 'All construals are equal, some are more equal than others' (Jessop 2015: 88). Such is already apparent from the earlier discussion of knowledge/ignorance and what is known let alone knowable. And, as Montgomerie and Williams (2009) observe, whilst there may have been mass participation in financialisation and, in that sense alone, democratic participation in free markets, interventionism has been increasingly for and by, if not confined to, an increasingly powerful (financial) elite, going far beyond the too big to fail (TBTF) syndrome as symbol of loss of democratic accountability.

More concretely, the closure of policymaking has been indicated by CRESC (2009: 5), finding that those UK bodies reporting on the financial system, and how better to regulate it, drew upon a membership of " 662 years of work experience and $75 \%$ of those years were spent in City [the London financial centre] occupations or servicing City needs'. Further, ' $90 \%$ of its witnesses came from finance or consultancy with revenue links to finance'. ${ }^{14}$ Indeed, 'Membership contained no non-financial businesses and their trade associations, no trade unions despite the unionisation of retail finance workers, no NGOs to represent consumers or press social justice agendas, no mainstream economists or heterodox 
This is the version of the article accepted for publication in New Political Economy published by Taylor \& Francis: http://dx.doi.org/10.1080/13563467.2017.1259299

Accepted version downloaded from SOAS Research Online: http://eprints.soas.ac.uk/23267/

intellectuals, very few politicians or civil servants', (CRESC 2009: 23). Significantly, even as witnesses, the representation of the public sector was notable for its absence.

What is both striking and disturbing is the extent to which different constituencies other than those attached to finance have been marginalised or subordinated, almost as second nature, within both the institutions and processes of government. This is part and parcel of the politics of neoliberalism more generally, a hollowing out of those institutions that challenge the dictates of the amorphous market. Nonetheless, any closure in the mcf cannot be selfcontained and totally exclusionary, and it is necessarily Contested, if only on conditions not necessarily made by (all of) the contestants, or equally so. For Dodd (2016: 269), neatly combining contestation with construal:

Culture is important to understanding the ways in which people shape money for themselves, bending it to their own purposes and resisting its capacity to homogenize everything it touches. This idea ought to be compelling ... not least because culture influences what money actually does.

Or in more mundane terms, we can highlight the slogan 'Quantitative Easing for the People'. What is striking of such contestation, however, especially in the wake of the crisis, is how much it is not only muted but also transformed in view of the commodification and closure attached to financialisation. To some degree, this can again be understood by parallel with consumption, and the distinction drawn between the consumer and the citizen. As argued in Fine (2005 and 2013), both these categories are limited in expressing conflicts of interest as all are both consumers and citizens. Nonetheless, the reduction of citizenship to financialised consumerism tends both to depoliticise and to disempower as will tend to occur with financialisation and individual responsibilisation. Or contestation can be driven to extremes, or out of the ordinary, as with street protests, the Occupy Movement (and its telling symbol of the 1 per cent). 
This is the version of the article accepted for publication in New Political Economy published by Taylor \& Francis: http://dx.doi.org/10.1080/13563467.2017.1259299

Accepted version downloaded from SOAS Research Online: http://eprints.soas.ac.uk/23267/

That financialisation is contested raises the elusive issue of power - what it is and how it is exercised. As Moran and Payne (2014: 33) observe:

Making sense of the power of financial markets faces what we might now do better to think of as 'the political science of political economy' with three big problems: the conceptualization of power itself; the conceptualization of markets; and the conceptualization of financial systems.

What does not seem to work analytically (possibly for financialisation and otherwise), however, is to seek out independent solutions for these issues, not least because conceptualisations of markets and financial systems already embody, at least implicitly, their own conceptualisations of power. Accordingly, Johal et al. (2014: 403) seek to pinpoint power through the bricolage of four (abstract) elements, 'the power of decision, the power of nondecision, the power of (narrative) hegemony and the power of learned self-discipline'. They then apply this to a history of the power of the UK's City during the past century, suggesting the exercise of different forms of power at different times as finance has sought to finesse both democratically-elected governments and the competitive workings of financial markets. ${ }^{15}$

Yet, it is far from clear to what extent the same power is being exercised and the same finance is exercising it, given the changes in the nature of each as well as the contexts within which they have operated. What is clear, though, is that contestation is inevitably Collective, especially if it is to be successful, whether collectivities promote financialisation (as with the newly emerged and/or strengthened financial elites) or resist it, however indirectly or effectively in street protests or through opposition to commercialisation. Of course, it might be argued that irrationally breaching a budget constraint is a form of dissent, a strike against Foucauldian governance, a material counter-culture. However, irrespective of its longevity 
This is the version of the article accepted for publication in New Political Economy published by Taylor \& Francis: http://dx.doi.org/10.1080/13563467.2017.1259299

Accepted version downloaded from SOAS Research Online: http://eprints.soas.ac.uk/23267/

and impact, it does in its own way conform to the material culture of financialisation rather than transform it.

And last, and by no means least, the material culture of financialisation is Chaotic in the sense of drawing together a multiplicity of practices and influences across a multiplicity of dimensions, with those being reflected upon by households themselves as they go about their daily lives, provisioning for life prospects and beyond. As Langley (2007: 82) puts it:

The subject position of the investor that is summoned up in neoliberal governmentality is represented as a paradoxically monolithic and disconnected economic identity. Indeed, the very isolation of the "the investor" provides the anchor point in representations of close relationships between the financial markets on the one hand and individual freedom and security on the other. Such isolation, of course, cannot hold, as investors are also simultaneously workers and consumers.

As a result, it follows that, 'Drawing attention to the contradictions present in the assembly of investor subjects is particularly important', p. 85. To impose a simple, or even complex, logic on the material culture of financialisation (the optimising or even behaviourally enriched punter) does seem inappropriate not least if reference is made to the telling examples of those experts, regulators, traders and scholars of the financial system itself let alone its humble customers. Yet, the material culture of financialisation ranges far beyond knowledge to the totalities of economic and social reproduction, on which financialisation has exerted an impact whether directly or indirectly.

\section{Concluding remarks}

Elsewhere it has been argued that financialisation lies at the heart of neoliberalism and explains its longevity, (Fine et al. 2015). But, of course, the material cultures of neoliberalism extend far beyond that of mere money. Or does it? In The Grapes of Wrath, Steinbeck observes, 'this tractor does two things - it turns the land and turns us off the land', and his 
This is the version of the article accepted for publication in New Political Economy published by Taylor \& Francis: http://dx.doi.org/10.1080/13563467.2017.1259299

Accepted version downloaded from SOAS Research Online: http://eprints.soas.ac.uk/23267/

novel charts the material cultures of those dispossessed. But the author also makes clear that behind the tractor and the land lies the banker whose bottom line must be met irrespective of the economic and social costs. The mcf is no different except that it exerts a longer, broader and deeper reach into our lives, however well this is acknowledged by those who gain and lose by it.

Not all of us can so skilfully as Steinbeck articulate the material and the cultural with narrative and imagery. This, though, has motivated the hunter/gatherer exercise that yielded the 10Cs, drawing upon the weapons of theoretical reflection and the instruments of case studies to solicit ways of framing material culture that avoid the Scylla of structural reductionism at one extreme and of free-floating semiotic readings at the other. Each of the 10Cs has the potential, contingent upon the object of study, to straddle the material and the cultural, albeit with different balances and content - consider the contradictory determinants of culture as opposed to its derived chaotic meanings for example. The studies that follow apply the 10Cs selectively, illustrating its elements across the diverse subject matters covered with, for example, commodification in practice of greater significance in underpinning owner-occupation and its corresponding cultures than delivery and content of financial literacy programmes although the latter would surely be different if inhabiting a world where money and credit matters less in light of decent wages, employment and public services free at the point of delivery.

\section{$\underline{\text { Footnotes }}$}

${ }^{1}$ See Fine (2013) for a recent account of its origins and evolution and various contributions.

See also Bayliss, Fine and Robertson (2013).

${ }^{2}$ But see, for example, Isakson (2014).

${ }^{3}$ This being drafted during the height of the horse meat scandal! 
This is the version of the article accepted for publication in New Political Economy published by Taylor \& Francis: http://dx.doi.org/10.1080/13563467.2017.1259299

Accepted version downloaded from SOAS Research Online: http://eprints.soas.ac.uk/23267/

${ }^{4}$ Although the SoP approach has also been applied to public provision, or public sector systems of provision, pssop.

${ }^{5}$ See especially Christophers (2013).

${ }^{6}$ See Langley (2008: 143) for whom:

instrumental rationality cannot be assumed to be an inherent feature of all modern monetary relations and all manner of financial networks. Rather, what we see are multiple monetary and financial networks in which the appearance of scientific rationality has to be secured and remade in specific forms, and remains contingent, contested, and open to (re)politicization.

From his perspective of financialisation as everyday (performative) life, there are resonances with the 10Cs approach as he ranges across financial inclusion and exclusion, inequality and networks, power, identity and dissent. Unsurprisingly, the implicit and, at times, explicit, presence of the $10 \mathrm{Cs}$ is pervasive across the literature.

${ }^{7}$ See also Svetlova (2012).

${ }^{8}$ On financial literacy, see Santos and Costa (2013), Santos (this issue) and Gabor and Brooks (this issue), and Fine (1998) for food.

${ }^{9}$ See also Engelen et al (2010) and Dixon and Ville-Pekka (2009) for pension provision as bricolage, and also Dorn (2012) and Thompson (2010). With his retrospective as Governor of the Bank of England replete with references to the importance of 'radical uncertainty', Mervyn King (2016: 123) asks, 'Why are we so reluctant to accept that the future is outside our control?' His own analysis is founded on four universals of the human condition, those of disequilibrium, radical uncertainty, cooperation (prisoners' dilemma) and trust - that might, as opposed to being specific to the second millennium's financial system, equally be applied to war through to marital breakdown! 
This is the version of the article accepted for publication in New Political Economy published by Taylor \& Francis: http://dx.doi.org/10.1080/13563467.2017.1259299

Accepted version downloaded from SOAS Research Online: http://eprints.soas.ac.uk/23267/

${ }^{10}$ As Executive Director for Financial Stability at the Bank of England. See also Haldane (2009 and 2010) and Cornford (2012).

${ }^{11}$ This is implicit in his use of metaphors to paint his picture, not only dogs catching frisbees but also sudoku, SARS, and so on, (Haldane 2012). See also Davies and McGoy (2012).

${ }^{12}$ See Davies and McGoey (2012).

${ }^{13}$ For financialisation and the Polanyian pendulum, or not, in the context of financialisation, see Watson (2009) and Konings (2009).

${ }^{14}$ For the Bischoff and Wigley Reports, respectively.

${ }^{15}$ But see Binderkrantz et al (2015) who emphasise the increasing coincidence of power across government, media and bureaucracy.

\section{$\underline{\text { References }}$}

Bayliss, K., Fine, B. and Robertson, R. (this issue), 'Introduction to Special Issue on the Material Cultures of Financialisation', New Political Economy, forthcoming.

Bayliss, K., Fine, B. and Robertson, M. (2013), 'From Financialisation to Consumption: The Systems of Provision Approach Applied to Housing and Water', FESSUD, Working Paper Series, no 02, Available from: http://fessud.eu/wp-content/uploads/2013/04/FESSUDWorking-Paper-021.pdf [Accessed: 15 December 2015]

Beggs, M., Bryan, D. and Rafferty, M. (2014), 'Shoplifters of the World Unite! Law and Culture in Financialized Times', Cultural Studies, 28 (5), pp. 976-96. 
This is the version of the article accepted for publication in New Political Economy published by Taylor \& Francis: http://dx.doi.org/10.1080/13563467.2017.1259299

Accepted version downloaded from SOAS Research Online: http://eprints.soas.ac.uk/23267/

Binderkrantz, A., Christiansen, P. and Pedersen, H. (2015), 'Interest Group Access to the

Bureaucracy, Parliament, and the Media', Governance, 28 (1), pp. 95-112.

Brassett, J., Rethel, L., and Watson, M. (2009), 'Introduction to the Political Economy of the Sub-prime Crisis in Britain: Constructing and Contesting Competence', British Journal of Politics and International Relations, 11 (3), pp. 377-81.

Christophers, B. (2013), Banking across Boundaries: Placing Finance in Capitalism (Chichester: Wiley-Blackwell).

Cook, N., Smith, S. and Searle, B. (2009), 'Mortgage Markets and Cultures of Consumption', Consumption, Markets and Culture, 12 (2), pp. 133-54.

Cornford, A. (2012), 'Of Dogs, Frisbees and the Complexity of Capital Requirements', Available from: http://www.networkideas.org/news/jan2013/pdf/Andrew_Cornford.pdf [Accessed: 15 December 2015]

CRESC (2009), An Alternative Report on UK Banking Reform, jointly authored by a working group of practitioners and academics based at the ESRC Centre for Research on Socio Cultural Change, University of Manchester, Available from:

http://www.cresc.ac.uk/publications/documents/AlternativereportonbankingV2.pdf

[Accessed: 15 December 2015]

Dixon, A. and Ville-Pekka, S. (2009), 'Institutional Change and the Financialisation of Pensions in Europe', Competition and Change, 13 (4), pp. 347-67.

Dodd, N. (2016), The Social Life of Money (Princeton: Princeton University Press).

Dorn, N. (2012), 'Knowing Markets: Would Less Be More?', Economy and Society, 41 (3), pp. 316-34.

Engelen, E., Erturk, I, Froud, J. Johal, S., Leaver, A. and Williams, K. (2010), 'Reconceptualizing Financial Innovation: Frame, Conjuncture and Bricolage', Economy and Society, 39 (1), pp. 33-63. 
This is the version of the article accepted for publication in New Political Economy published by Taylor \& Francis: http://dx.doi.org/10.1080/13563467.2017.1259299

Accepted version downloaded from SOAS Research Online: http://eprints.soas.ac.uk/23267/

Engelen, E., Erturk, I., Froud, J., Johal, S., Leaver, A., Moran, M. and Williams, K. (2012),

'Misrule of Experts?: The Financial Crisis as Elite Debacle', Economy and Society, 41 (3), pp. 360-82.

Erturk, I., Froud, J., Johal, S., Leaver, A., and Williams, K. (eds) (2008), Financialization at Work: Key Texts and Commentary (London: Routledge).

Fine, B. (1993), 'Resolving the Diet Paradox', Social Science Information, 32 (4), pp. 66987.

Fine, B. (1995), ‘Towards a Political Economy of Anorexia?', Appetite, 24 (3), pp. 231-42.

Fine, B. (1998), The Political Economy of Diet, Health and Food Policy (London:

Routledge).

Fine, B. (2002), The World of Consumption: The Cultural and Material Revisited (London: Routledge).

Fine, B. (2005), 'Addressing the Consumer', in F. Trentmann (ed.), The Making of the Consumer: Knowledge, Power and Identity in the Modern World (Oxford: Berg), pp. 291311.

Fine, B. (2013), 'Consumption Matters', Ephemera, 13 (2), pp. 217-48, Available from: http://www.ephemerajournal.org/contribution/consumption-matters [Accessed: 15 December 2015]

Fine, B. (2016), 'From Performativity to the Material Culture of Legal Expertise?', London Review of International Law, forthcoming.

Fine, B. and Lapavitsas, C. (2000), 'Markets and Money in Social Theory: What Role for Economics?', Economic and Society, 29 (3), pp. 357-82.

Fine, B., Saad-Filho, A., Bayliss, K. and Robertson, M. (2015), 'Thirteen Things You Need to Know about Neoliberalism' FESSUD, Working Paper Series, no 155, Available from 
This is the version of the article accepted for publication in New Political Economy published by Taylor \& Francis:

http://dx.doi.org/10.1080/13563467.2017.1259299

Accepted version downloaded from SOAS Research Online: http://eprints.soas.ac.uk/23267/

http://fessud.eu/wp-content/uploads/2015/03/13-Things-you-need-to-know-about-

Neoliberalism-working-paper155.pdf [Accessed 30 September 2016].

Finlayson, A. (2009), 'Financialisation, Financial Literacy and Asset-Based Welfare', British Journal of Politics and International Relations, 11 (3), pp. 400-21.

Fischler, C. (1980), 'Food Habits, Social Change, and the Nature/Culture Dilemma,' Social Science Information, 19 (6), pp. 937-53.

Fischler, C. (1988), 'Food, Self, and Identity,' Social Science Information, 27 (2), pp. 275-92.

Gabor, D. and Brooks, S. (this issue), 'Financial Inclusion', New Political Economy, forthcoming.

Haiven, M. (2014), Cultures of Financialization: Fictitious Capital in Popular Culture and Everyday Life (Basingstoke: Palgrave MacMillan).

Haldane, A. (2009), 'Rethinking the Financial Network', presented at the Financial Student Association, 28 April, Available from:

http://www.bankofengland.co.uk/publications/speeches/2009/speech386.pdf [Accessed: 15

December 2015]

Haldane, A. (2010), ‘The \$100 Billion Question', presented at the Institute of Regulation and Risk, Hong Kong, 30 March. Available from: http://www.bis.org/review/r100406d.pdf [Accessed: 2 October 2016]

Haldane, A. (2012), 'The Dog and the Frisbee', speech given at the Federal Reserve Bank of Kansas City's 36th economic policy symposium, 'The Changing Policy Landscape', Jackson Hole, Wyoming, 31 August, Available from:

http://www.bankofengland.co.uk/publications/Documents/speeches/2012/speech596.pdf [Accessed: 15 December 2015]

Happer, C. (this issue), 'Financialisation, Media and Social Change', New Political Economy, forthcoming. 
This is the version of the article accepted for publication in New Political Economy published by Taylor \& Francis: http://dx.doi.org/10.1080/13563467.2017.1259299

Accepted version downloaded from SOAS Research Online: http://eprints.soas.ac.uk/23267/

Haug, W. (1986), Critique of Commodity Aesthetics: Appearance, Sexuality and Advertising in Capitalist Society (London: Polity Press).

Isakson, S. (2014), 'Food and Finance: The Financial Transformation of Agro-Food Supply Chains', Journal of Peasant Studies, 41 (5), pp. pp. 749-75.

Jessop, B. (2015), 'Neoliberalism, Finance-Dominated Accumulation and Enduring Austerity: A Cultural Political Economy Perspective', in K. Farnsworth and K. Irving (eds) Social Policy in Times of Austerity: Towards a New International Political Economy of Welfare (Bristol: Policy Press).

Johal, S., Moran, M. and Williams, K. (2014), 'Power, Politics and the City of London after the Great Financial Crisis', Government and Opposition, 49 (3), pp. 400-25.

Karacimen, E. (2014), 'Dynamics behind the Rise in Household Debt in Advanced Capitalist Countries: An Overview', FESSUD, Working Paper Series, no 9, Available from:

http://fessud.eu/wp-content/uploads/2013/04/Dynamics-behind-the-Rise-in-Household-DebtFESSUD-Working-Paper-09-1.pdf [Accessed: 15 December 2015]

King, M. (2016), The End of Alchemy: Money, Banking and the Future of the Global Economy (London: Little Brown).

Konings, M. (2009), 'Rethinking Neoliberalism and the Subprime Crisis: Beyond the Reregulation Agenda', Competition and Change, 13 (2), pp. 108-27.

Langley, P. (2007), 'Uncertain Subjects of Anglo-American Financialization', Cultural Critique, 65 (Fall), pp. 67-91.

Langley, P. (2008), The Everyday Life of Global Finance: Saving and Borrowing in AngloAmerica (Oxford: Oxford University Press).

Lapavitsas, C. (2003), Social Foundations of Markets, Money and Credit (London: Routledge). 
This is the version of the article accepted for publication in New Political Economy published by Taylor \& Francis: http://dx.doi.org/10.1080/13563467.2017.1259299

Accepted version downloaded from SOAS Research Online: http://eprints.soas.ac.uk/23267/

MacKenzie, D. (2008), An Engine, Not a Camera: How Financial Models Shape Markets (Cambridge: MIT Press).

Mellor, M. (2016), Debt or Democracy: Public Money for Sustainability and Social Justice (London: Pluto).

Montgomerie, J. and Williams, K. (2009), 'Financialised Capitalism: After the Crisis and Beyond Neoliberalism', Competition and Change, 13 (2), pp. 99-107.

Moran, M. and A. Payne (2014), 'Introduction: Neglecting, Rediscovering and Thinking Again about Power in Finance', Government and Opposition, 49 (3), pp. 331-41.

Payne, C. (2012), The Consumer, Credit and Debt: Governing the Modern Economy (London: Routledge).

Robertson, M. (this issue), '(De)constructing the Financialised Culture of Owner-Occupation in the UK, with the Aid of the 10Cs', New Political Economy, forthcoming.

Santos, A. (this issue), 'Cultivating the Self-Reliant and Responsible Individual: The Material Culture of Financial Literacy', New Political Economy, forthcoming.

Santos, A. and Costa, V. (2013), 'Financial Literacy and Consumer Protection in the Midst of Financial Crisis: Underlying Presuppositions and Alternative Approaches', mimeo.

Svetlova, E. (2012), 'On the Performative Power of Financial Models', Economy and Society, 41 (3), pp. 418-34.

Thompson, G. (2010), 'The Global Regulatory Consequences of an Irrational Crisis:

Examining ‘Animal Spirits’ and 'Excessive Exuberances', Globalizations, 7 (1-2), pp. 87103.

Zelizer, V. (1994), The Social Meaning of Money (New York: Basic Books).

Zelizer, V. (1996), 'Payments and Social Ties', Sociological Forum, 11 (3), pp. 481-95.

Zelizer, V. (1998), 'The Proliferation of Social Currencies', in M. Callon (ed.), The Laws of the Market, (Oxford: Blackwell). 
This is the version of the article accepted for publication in New Political Economy published by Taylor \& Francis: http://dx.doi.org/10.1080/13563467.2017.1259299

Accepted version downloaded from SOAS Research Online: http://eprints.soas.ac.uk/23267/

Zelizer, V. (2000), 'Fine-Tuning the Zelizer View', Economy and Society, 29 (3), pp. 383-89. 